\title{
Emilia Garncarek*
}

(iD) https://orcid.org/0000-0002-9685-0741

\author{
Agata Matuszewska-Kubicz**
}

iD https://orcid.org/0000-0002-5808-4644

\section{YOUNG WOMEN'S (MOTHER'S) NEEDS AND EXPECTATIONS REGARDING THE DEVELOPMENT OF PROFESSIONAL COMPETENCES - A COMPARATIVE ANALYSIS OF RESEARCH RESULTS FROM POLAND, LITHUANIA, SPAIN AND CYPRUS}

\begin{abstract}
Over the last two decades, there has been a significant improvement in the participation of women in education and the labour market in the European Union. Nevertheless, there are still many challenges to improving the situation of women. The excessive burden of household duties is a major barrier to the educational and professional activity of women, especially young women with small children. Apart from the inability to balance work and personal life, other factors limiting women's professional activity include the mismatch between their education and the challenges of the modern labour market. Although the majority of people with higher education are women, when planning their careers, they tend to choose less attractive courses of study which are not linked to the professions of the future. The text presents the results of an analysis of research on the needs and expectations of young women (mothers) regarding the development of professional competences. The results show in which types of activities raising competences the surveyed women participate; how they evaluate the effectiveness of activities raising their competences in the professional area; what factors influence the decision of women to participate in the selected form of training; what are the attitudes of the external environment of the surveyed women towards their participation in training; what problems the surveyed women encounter in connection with participation in training raising their professional competences. The focus was on similarities and differences in statements of young women (mothers) from Poland, Lithuania, Spain and Cyprus who participating in the international project Mommypreneurs.
\end{abstract}

Keywords: young women, mothers, trainings, competences, labour market, EU, Mommypreneurs project.

* $\mathrm{PhD}$, Katedra Socjologii Struktur i Zmian Społecznych, Instytut Socjologii, Wydział Ekonomiczno-Socjologiczny, Uniwersytet Łódzki, ul. Rewolucji 1905 r. 41/43, 90-214 Łódź, e-mail: emilia.garncarek@uni.lodz.pl

** PhD, Katedra Pracy i Polityki Społecznej, Instytut Logistyki i Informatyki, Wydział Ekonomiczno-Socjologiczny, Uniwersytet Łódzki, ul. Rewolucji 1905 r. 37, 90-214 Łódź, e-mail: agata.matuszewska@uni.lodz.pl 


\section{Introduction}

Over the last two decades, the European Union has experienced a significant improvement in women's participation in the education process and labour market. This results both from long-term trends evident across developed countries, and from changes made to institutional frameworks in specific countries. For years, many European countries have been taking successive initiatives to ensure equal treatment of women and men in employment. Special programmes, training aimed at women, as well as legislation can be pointed to. Nevertheless, there are still many challenges to improve the situation of women, especially the situation of young women - mothers. The excessive burden of household duties is the main barrier to the educational and professional activity of women, especially young women who have small children. Apart from the inability to find a balance between work and personal life, other factors limiting the professional activity of women include inadequacy of their education to the challenges of the contemporary labour market. Another barrier hindering women's participation in the labour market are gender stereotypes functioning in societies, acquired in the process of socialisation. Gender stereotypes make women themselves afraid to apply for attractive jobs, underestimating the value of their competences. Active women are also confronted with stereotyped prejudices and direct discrimination, whether in recruitment or later in employment. They face difficulties in accessing training, are less likely to be promoted, and sporadically hold the highest and best paid positions in the corporate hierarchy. The situation of young women (especially mothers), in the area concerned is even more difficult (Luka płacowa 2020).

\section{Young women on the EU labour market}

Although in recent years there has been a noticeable reducing of the gender gap on the labour market in the European Union, unfortunately it still remains relatively high in the 25-29 age group. Young women are more often inactive than young men, and if they are employed, they hold low-paid part-time or temporary jobs. This is the case even if they have a high level of education. As the researchers point out, this is due, among other things, to social expectations of women, including their being burdened with more family responsibilities than young men. Another reason is the segregation of the sexes in education and training systems, which leads to, inter alia, skills mismatches, difficult access to job search mechanisms, and discrimination in the labour market. The different conditions faced by young men and young women also imply differences between them in aspects such as employment policies and work-life reconciliation (e.g. Titkow et al. 2004; Szlendak 2010; Dzwonkowska-Godula, Garncarek 2013; Garncarek 2013; Szyszka 2016; Loi et al. 2017; Słowik 2020). 
In $2019,15.1 \%$ of young people aged $15-24$ and $9.1 \%$ of young people aged 25-29 were unemployed in the European Union. Unemployment rates were higher for the younger age group in each European Union member state. In October 2020 , the youth unemployment rate was $17.5 \%$ in the EU and $18.0 \%$ in the euro area. It was rising in the wake of the global financial and economic crisis and the Covid-19 pandemic, with the youth unemployment rate rising at a faster rate than the overall population. ${ }^{1}$

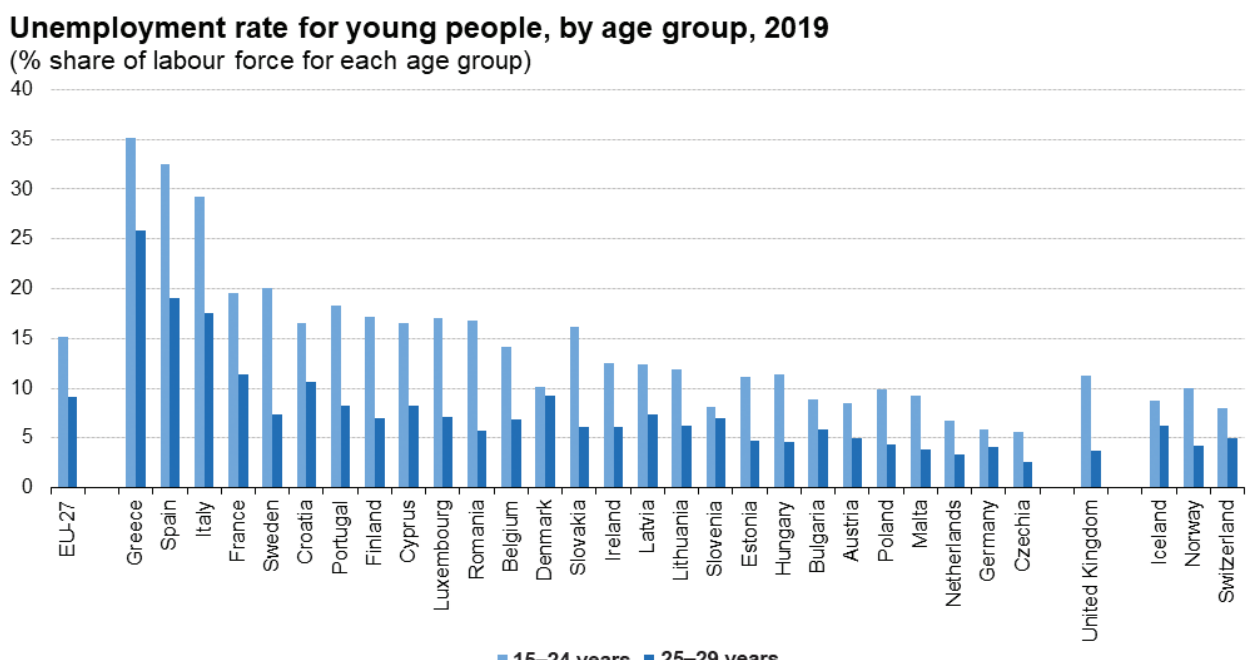

15-24 years $\approx$ 25-29 years

Note: ranked on the rate for all young people aged 15-29 years. Source: Eurostat (online data code: yth_empl_100)

eurostat?

Chart 1. Unemployment rate for young people in EU (2019) based on Eurostat Source: Eurostat, https://ec.europa.eu/eurostat/statistics-explained/index. php?title=File:Unemployment_rate_for_young_people,_by_age_group,_2019_(\%25_share_of_ labour_force_for_each_age_group)_BYIE20.png (accessed: 7.06.2021).

Characteristic of youth employment rates across Europe is the existence of gender differences. The gender gap is particularly significant for NEET (Neither in Employment nor in Education or Training) rates in the 25-29 age cohort. Young women in almost all European countries are more likely to be unemployed and have worse employment conditions than men. They are more often in part-time

1 The unemployment situation of young people aged 15-24 differs significantly across EU Member States. In 2019, the highest unemployment rates were recorded in Greece (where more than a third of the workforce aged 15-24 was unemployed - 35.2\%), Spain and Italy. In contrast, at the other end of the range, the lowest unemployment rates for the 15-24 age group were recorded in the Czech Republic (5.6\%) and Germany (5.8\%). An analysis of the gap in unemployment rates between young people aged 15-24 and young people aged 25-29 shows that the biggest differences are generally found in EU Member States with some of the highest overall unemployment rates (Eurostat 2020). 
and/or fixed-term jobs and receive lower wages than young men. Although there are hardly any differences among 15-24 year-olds, they increase dramatically among older NEETS (aged 20+), as shown in the Chart 2.

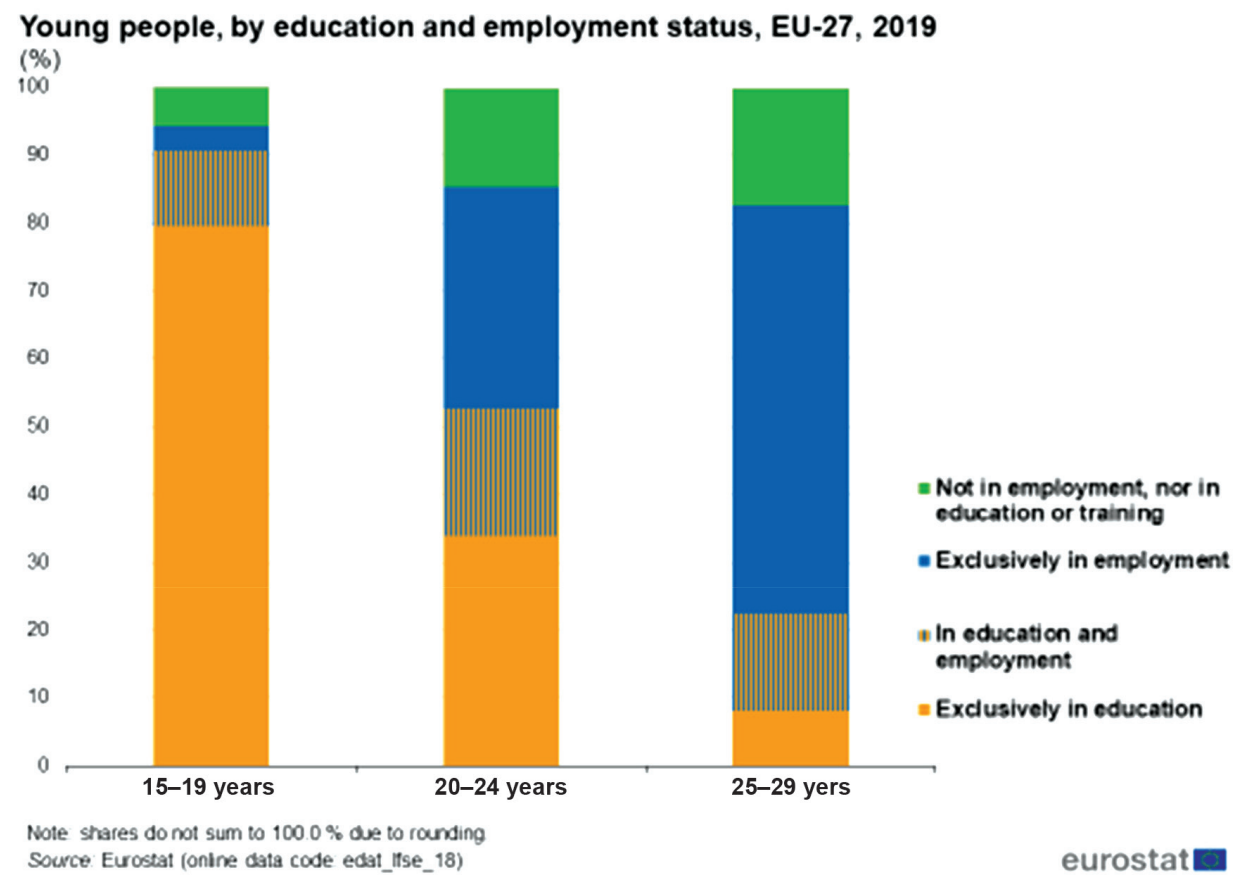

Chart 2. Young people by education and employment status based on Eurostat

Source: Eurostat 2020.

\section{Specific situation of young women returning to the labour market after a break due to childbirth}

Numerous studies show that in European countries the situation of young women, especially mothers, who want to return to the labour market after a break due to childbirth is relatively difficult. It often means falling out of the labour market and into long-term unemployment (Rękas 2013; Dobroszek 2021). Despite positive trends in the professional activation of this category of women, access to a decent labour market is still a challenge for them (Mikołajczyk, Stankowska 2021).

According to the OECD, there are significant differences in employment rates between women and men ( $20.6 \%$ on average - to the disadvantage of women). In particular, young women caring for children are one of the groups most at risk of professional exclusion. Around $20 \%$ of women who do not work say that childcare responsibilities block their participation in the labour market. 
According to the Equality and Human Rights Commission (UK) (Pregnancy and Maternity 2018a; Pregnancy and Maternity 2018b), every year more than $7 \%$ of women lose their jobs due to pregnancy, $45 \%$ suffer some financial loss and $50 \%$ are less likely to apply for promotion. Studies also point to the persistence of pay inequalities, as well as the phenomenon of the so-called "maternity penalty", which generates a decrease in women's pay of $7 \%$ in the case of childbirth and of $3-5.7 \%$ in the case of a year of maternity leave. It is worth noting that the return of young women-mothers to work also depends on a large extent on their skills and competences. While $94.6 \%$ of women with high professional qualifications return to the labour market after their maternity leave, only $56.8 \%$ of women with low qualifications return. ${ }^{2}$ According to Poland data - GUS (2019) - almost half of mothers of children under 3 do not return to work. Having children also affects the level of remuneration - mothers earn less not only than men, but also than other women who have not decided to become mothers.

Deep social and cultural changes are needed to change the unfavourable situation of women (especially young mothers) in the labour market. It is essential, among other things, to overcome unconscious prejudices and stereotypes which keep women in an inferior position to men. There is a need for constant changes in social policy, especially with regard to the family, which should support young women in maintaining a work-life balance. In particular, attention should be paid to improving public childcare - increasing the availability of affordable and good quality childcare facilities. Only the absence of obstacles to access to institutional care, a real alternative to parental care, as well as access to flexible forms of work or the possibility to work from home can contribute to reducing gender gaps in the labour market. Policies that promote women's access to education, training or that foster re-entry into the labour market are particularly important for achieving young women's full participation in social and economic life (Loi et al. 2017; Macierzyństwo 2021).

As many researchers underline, one of the most important factors of human capital is broadly understood education, visible in obtaining formal education, as well as participation in various supplementary courses/trainings. People with higher education are generally characterised by greater entrepreneurship, innovation and creativity, features which have a significant impact on the absorption of modern technologies and organisational solutions, which leads to the socio-economic development of entire societies (Rokicka, Przybylski 2012). They are also perceived by employers as people with higher qualifications, adaptability, independence in performing tasks and orientation towards success (Socha, Sztanderska 2002). Such characteristics increase the possibility of obtaining a (good) job by better educated people. Thus, education, qualifications

${ }^{2}$ https://www.equalityhumanrights.com/en/managing-pregnancy-and-maternity-workplace/ pregnancy-and-maternity-discrimination-research-findings (accessed: 20.12.2020). 
and high competences have a positive impact on an individual's position in the labour market, which is confirmed by the characteristics of the structure of the unemployed (GUS 2020). They also play an indirect role in shaping the quality of life through their impact on income and a sense of security in the labour market (Dolan et al. 2008). The benefits of human capital accumulation also include greater access to good jobs and higher incomes and positions held (Domański 1993), which reduces the fear of losing job stability (Ross, Van Willigen 1997).

In view of the still unfavourable situation of women in the discussed issue, both educational institutions and young women themselves should pay attention to the problem of mismatch between women's competences and skills and the needs of the modern labour market and take actions aimed at changing this unfavourable situation. Adapting to current requirements, e.g. by providing training in entrepreneurship and modern digital technologies, would allow women to have a "contingency plan" in case they return to the labour market after a break due to childbirth.

\section{Purpose, research issues and methodology of the study}

As it results from the above considerations, lifelong learning, development of competences, sometimes retraining, adjusting to the requirements of the modern labour market, give a better chance to maintain professional activity and avoid socio-economic exclusion. It should also be remembered that making the decision to participate in various courses, trainings, studies, also fulfils autotelic needs, related to self-development and self-realisation, which may result in improving the quality of life of the individual, as well as his/her social well-being. This knowledge motivated the partners of an international consortium to carry out a research and training project "Mommypreneurs". ${ }^{3}$

The "Mommypreneurs" project was implemented in Poland, Spain, Portugal, Romania, Lithuania, Cyprus and Italy, so in countries that represent a variety of systems for helping young women returning to the labour market after childbirth, as well as different socio-cultural patterns of the maternal role. Although the challenges in these countries vary, they all face similar problems, such as female unemployment and career interruptions due to maternity leave.

According to the European Union Labour Force Survey, in all project countries women without children have higher employment rates than those with children. The difference is 25\% in the case of Poland, 21\% in Cyprus, $20 \%$ in Italy, $19 \%$ in Spain, $15 \%$ in Portugal, $11 \%$ in Romania and 3\% in Lithuania

3 "Mommypreneurs" Project (2019-2021) was co-financed by Norwegian funds, implemented in the framework of an international programme EEA and Norway Grants Found for Youth Employment under an agreement concluded with an international organisation or foreign entity EEA and Norway Grants Found for Youth Employment No. 2017-1-277. 
for women aged 25-29. The analysis shows that employers in all participating countries use different pressure tactics to force pregnant women and mothers to give up their jobs (e.g. by "mobbing", "freezing" wages or not promoting to higher positions). Restrictions in the childcare system, such as a limited network of kindergartens, the lack or limitation of childcare at workplaces and expensive childcare services influencing the exclusion of young women from the labour market.

"Mommypreneurs" project had a dual nature - research and training. As a part of the research part of the project, a questionnaire survey was carried out among female trainees in four selected countries of the consortium - Poland, Lithuania, Spain and Cyprus. The first part of the research consisted in the content analysis of existing data on the situation of young women-mothers in the context of combining their private/family life with public/professional life, in particular the issue of re-entering the labour market after a break related to childbirth. The second part of the study (the main one) - on conducting a survey in selected partner countries of the consortium. An online survey technique (CAWI) was used. The survey was conducted between April 2020 and February 2021. The main objective of the study was to identify motives, expectations, stimulators and barriers to undertaking training activity by young women (mainly mothers) in selected countries of the project consortium. In order to achieve the research objective, the following research question was posed - What differences exist between women from selected EU countries in terms of their undertaking training activities aimed at developing their human capital and improving their situation on the labour market? Accordingly, five specific research questions were posed:

1) In which types of competence enhancement activities the interviewed women participate in?

2) How do the surveyed women assess the effectiveness of activities raising the level of competences in the professional area?

3) What factors influence the respondents' decision to participate in the chosen form of training?

4) What are the attitudes of respondents' external environment to their participation in training?

5) What problems do the respondents' encounter in connection with their participation in trainings?

\section{Characteristics of the research sample}

The study involved a total of 217 women from four European Union countries (Poland, Lithuania, Spain, Cyprus) who participated in the project "Mommypreneurs". The characteristics of the research sample are presented in Table 1. 
Table 1. Characteristics of the research sample

\begin{tabular}{|c|c|c|c|c|c|c|}
\hline Country & $\begin{array}{l}\text { Sample } \\
\text { (N) }\end{array}$ & Age & Education & $\begin{array}{c}\text { How many of } \\
\text { women are } \\
\text { mothers? }\end{array}$ & $\begin{array}{l}\text { How many } \\
\text { of women is } \\
\text { raising their } \\
\text { child/children } \\
\text { together with } \\
\text { the father } \\
\text { of the child/ } \\
\text { children? }\end{array}$ & $\begin{array}{l}\text { Personal } \\
\text { situation }\end{array}$ \\
\hline Poland & 62 & $\begin{array}{c}21-38 \\
\text { years }\end{array}$ & $\begin{array}{c}63 \% \text { master } \\
\text { degree; } 13 \% \\
\text { bachelor } \\
\text { degree; } 24 \% \\
\text { - general } \\
\text { secondary } \\
\text { education }\end{array}$ & $\begin{array}{l}55(64 \% \text { of } \\
\text { one child, } \\
31 \% \text { of two } \\
\text { children })\end{array}$ & $87 \%$ & $\begin{array}{c}73 \% \text { are } \\
\text { married; } \\
14 \% \text { live } \\
\text { in informal } \\
\text { relationships }\end{array}$ \\
\hline Lithuania & 47 & $\begin{array}{c}22-39 \\
\text { years }\end{array}$ & $\begin{array}{c}38 \% \text { master } \\
\text { degree; } 55 \% \\
\text { bachelor } \\
\text { degree }\end{array}$ & $\begin{array}{l}47(70 \% \text { of } \\
\text { one child, } \\
23 \% \text { of two } \\
\text { children })\end{array}$ & $96 \%$ & $\begin{array}{l}92 \% \text { are } \\
\text { married }\end{array}$ \\
\hline Spain & 76 & $\begin{array}{l}18-60 \\
\text { years }\end{array}$ & $\begin{array}{c}22 \% \text { master } \\
\text { degree; } 33 \% \\
\text { bachelor } \\
\text { degree; } 21 \%- \\
\text { high school }\end{array}$ & $\begin{array}{l}32(66 \% \text { of } \\
\text { one child, } \\
34 \% \text { of two } \\
\text { children })\end{array}$ & $59 \%$ & $\begin{array}{c}37 \% \text { live } \\
\text { in informal } \\
\text { relationships; } \\
36 \% \text { are } \\
\text { single; } 24 \% \\
\text { are married }\end{array}$ \\
\hline Cyprus & 32 & $\begin{array}{c}21-39 \\
\text { years }\end{array}$ & $\begin{array}{c}37 \% \text { master } \\
\text { degree; } 63 \% \\
\text { bachelor } \\
\text { degree }\end{array}$ & $\begin{array}{l}20(60 \% \text { of } \\
\text { one child, } \\
30 \% \text { of two } \\
\text { children })\end{array}$ & $80 \%$ & $\begin{array}{c}50 \% \text { are } \\
\text { married; } 25 \% \\
\text { are single; } \\
16 \% \text { live } \\
\text { in informal } \\
\text { relationships }\end{array}$ \\
\hline
\end{tabular}

Source: own study.

\section{Results}

The first research question was about the participation of women in competence enhancement activities. In every country, the majority of respondents participated in competence enhancement activities other than the "Mommypreneurs" Project; the highest percentage in Cyprus (72\%), the lowest in Poland (56\%). Among the groups of respondents who participated in competence enhancement activities, vocational training (in Poland and Spain) and soft skills training (in Lithuania and Cyprus) were the most popular. Clear differences between countries can be seen in the popularity of language courses, which were definitely more popular among 
respondents from Spain (48\%) and Cyprus (56\%). It is also worth noting that postgraduate studies are by far the most popular in Cyprus (48\%), compared to the other surveyed countries. Detailed results are presented in Chart 3.

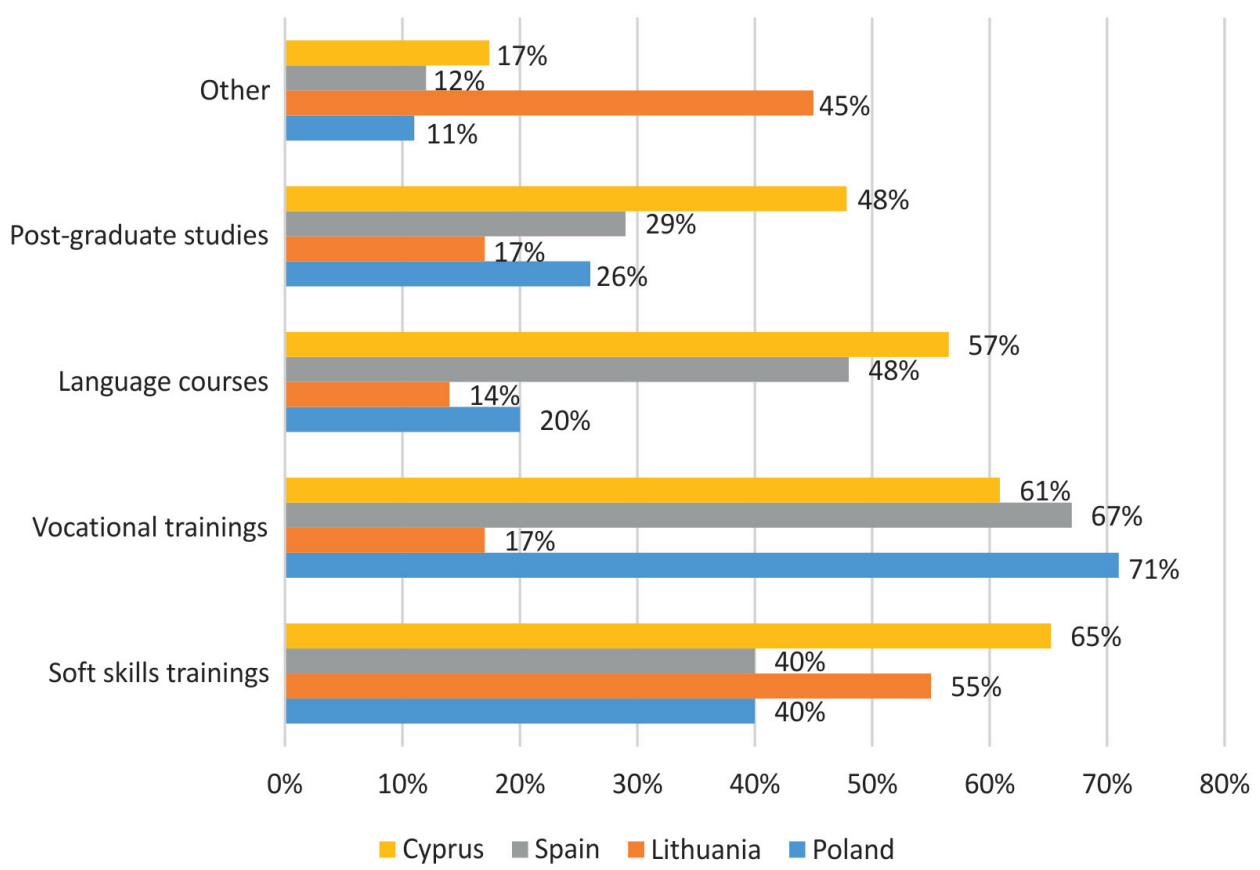

Chart 3. Participation of respondents in competence building activities Source: own study $(\mathrm{N}=139)$.

Respondents were also asked about the number of competence enhancement activities they participated in. In case of respondents from Poland, Lithuania and Cyprus the most common answer (mode) was two activities, whereas respondents from Spain most often indicated five activities.

The second research question concerned the evaluation of the effectiveness of activities raising the level of competences in the professional area. Respondents were asked if the actions they took helped them to find a job, change a job to a better one or get a promotion at work. About half of the respondents in Poland (46\%), Spain $(44 \%)$ and Cyprus (52\%) answered in the affirmative. A much lower percentage of affirmative answers was recorded among respondents in Lithuania (28\%).

The next research question concerned the factors influencing the respondents' decision to participate in the chosen form of training. In all the researched countries the key aspect turned out to be the attractive topic of the training; this element was indicated as very important or rather important by $94 \%$ of respondents from Poland, $85 \%$ from Lithuania, 84\% from Spain and 88\% from Cyprus. In all surveyed countries the following elements were also indicated as important or 
rather important by the majority of respondents: free of charge training (85\% in Poland, 66\% in Lithuania, 71\% in Spain, $81 \%$ in Cyprus) and attractive and easily accessible locations of training (73\% in Poland, $57 \%$ in Lithuania, $63 \%$ in Spain, $72 \%$ in Cyprus). It is worth noting that differences between the surveyed countries emerged in the case of the criterion "training is (co)organised by an entity that is an employer and provides employment opportunities" and "training organised by the government or a public institution". These factors turned out to be much less important for respondents from Lithuania, compared to the other countries surveyed. Detailed results are presented in Chart 4.

The trainings are organized by the government or by a public institution

The trainings are (co)organized by the entity that is the employer and provides the opportunity to employ the best training participants

The trainings locationsare attractive and easily accessible

The trainings topics are attractive

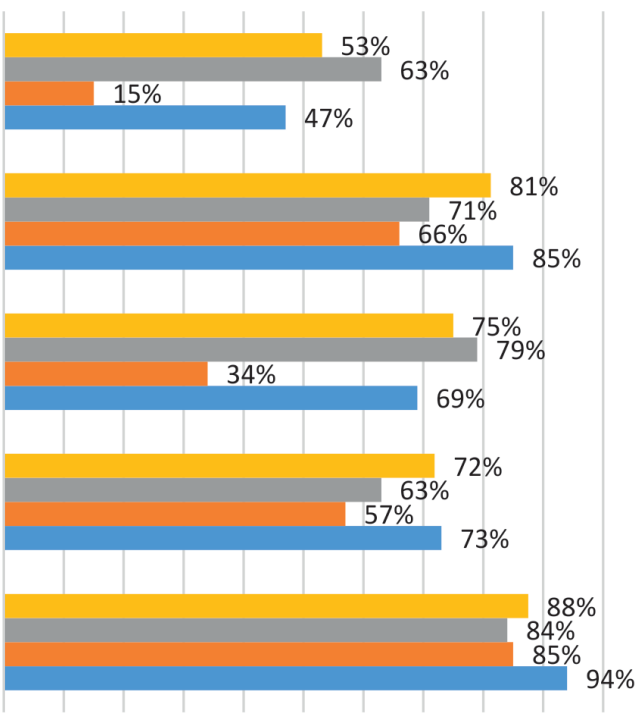

0\% $10 \%$ 20\% 30\% 40\% 50\% 60\% 70\% 80\% $90 \% 100 \%$

Cyprus Spain $\square$ Lithuania Poland

Chart 4. Very/rather important factors influencing participation in training Source: own study $(\mathrm{N}=217)$.

These distributions have also been confirmed in the analysis of the most frequent answers (mode), which are presented in Table 2. In the case of respondents from Cyprus, Spain and Poland all or almost all of the indicated aspects were most often assessed as very important factors affecting the decision on participation in the selected form of training. Only in the case of respondents from Lithuania we can notice a differentiation in the importance of the examined factors. The fact that the training is organised by the government or a public institution was most often not at all important for the respondents, and the fact that the training is (co-)organised by an entity which is an employer and provides employment opportunities was most often assessed as neutral. 
Table 2. Most frequent answers (mode) to questions regarding factors influencing participation in training

\begin{tabular}{|l|c|c|c|c|}
\hline \multicolumn{1}{|c|}{$\begin{array}{c}\text { Questions regarding factors } \\
\text { influencing participation in training }\end{array}$} & Cyprus & Spain & Lithuania & Poland \\
\hline $\begin{array}{l}\text { How important to you is that the } \\
\text { trainings locations are attractive and } \\
\text { easily accessible (well-connected or } \\
\text { located in the city center)? }\end{array}$ & $\begin{array}{c}\text { very } \\
\text { important }\end{array}$ & $\begin{array}{c}\text { very } \\
\text { important }\end{array}$ & $\begin{array}{c}\text { very } \\
\text { important }\end{array}$ & $\begin{array}{c}\text { very } \\
\text { important }\end{array}$ \\
\hline $\begin{array}{l}\text { How important to you is that the } \\
\text { trainings topics are attractive? }\end{array}$ & $\begin{array}{c}\text { very } \\
\text { important }\end{array}$ & $\begin{array}{c}\text { very } \\
\text { important }\end{array}$ & $\begin{array}{c}\text { very } \\
\text { important }\end{array}$ & $\begin{array}{c}\text { very } \\
\text { important }\end{array}$ \\
\hline $\begin{array}{l}\text { How important to you is that the } \\
\text { trainings are (co-)organised by } \\
\text { the entity that is the employer and } \\
\text { provides the opportunity to employ } \\
\text { the best training participants? }\end{array}$ & $\begin{array}{c}\text { very } \\
\text { important }\end{array}$ & $\begin{array}{c}\text { very } \\
\text { important }\end{array}$ & neutral & $\begin{array}{c}\text { very } \\
\text { important }\end{array}$ \\
\hline $\begin{array}{l}\text { How important to you is that } \\
\text { participation in the trainings is free? }\end{array}$ & $\begin{array}{c}\text { very } \\
\text { important }\end{array}$ & $\begin{array}{c}\text { very } \\
\text { important }\end{array}$ & $\begin{array}{c}\text { very } \\
\text { important }\end{array}$ & $\begin{array}{c}\text { very } \\
\text { important }\end{array}$ \\
\hline $\begin{array}{l}\text { How important to you is that the } \\
\text { trainings are organised by the state } \\
\text { or by a public institution (e.g. a state } \\
\text { university)? }\end{array}$ & $\begin{array}{c}\text { very } \\
\text { important }\end{array}$ & $\begin{array}{c}\text { very } \\
\text { important }\end{array}$ & $\begin{array}{c}\text { important } \\
\text { at all }\end{array}$ & $\begin{array}{c}\text { rather } \\
\text { important }\end{array}$ \\
\hline
\end{tabular}

Source: own study $(\mathrm{N}=217)$.

Regarding the needs of the interviewed women in the field of participation in competence enhancement activities, the respondents were also asked about the most beneficial time for them when the training should take place. In this aspect, the opinions of respondents varied according to their countries of origin. In Lithuania, the majority of respondents (64\%) prefer the afternoon/evening hours of the week. For most of the Spanish women (58\%) and half of the Cypriots $(50 \%)$ the morning hours of the week are preferable. The opinions of Polish women, on the other hand, are mixed, with $40 \%$ saying that afternoon/evening hours during the week are most convenient for them, but slightly less (34\%) preferring morning hours during the week.

In the area of women's expectations concerning the participation in the activities improving competences, the respondents were also asked about their preferred form of training. In this regard, the needs also turned out to be different between the surveyed countries. About half of the respondents from Poland $(50 \%)$ and Spain (59\%) prefer a completely online form of training. On the other hand, most of the surveyed women from Lithuania (66\%) and Cyprus (56\%) claim that the most convenient for them is a mixed form of training - training carried out partly stationary and partly online.

Another research question concerned the attitude of respondents' external environment to their participation in training. Regarding the support received 
from family members, in all surveyed countries, a vast majority of women believe that family members supported them very much or rather $(86 \%$ in Poland, $90 \%$ in Lithuania, $83 \%$ in Spain, $97 \%$ in Cyprus). Similar, although slightly lower, indications were found for the attitudes of the respondents' friends and acquaintances. In this case as well, the majority of female respondents, regardless of their country of origin, felt that their friends and acquaintances supported them very much or rather $(84 \%$ in Poland, $89 \%$ in Lithuania, $83 \%$ in Spain, $72 \%$ in Cyprus). The results are presented in Chart 5.

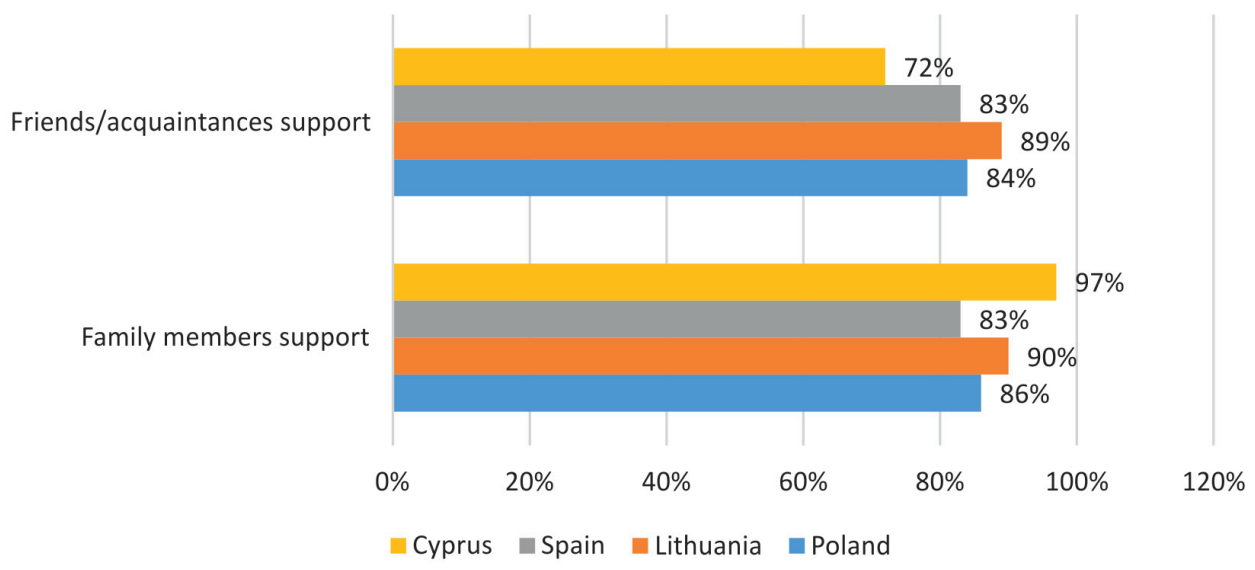

Chart 5. Support (rather support) from family members and friends/acquaintances

Source: own study $(\mathrm{N}=217)$.

The last research question concerned the perceived problems hindering respondents from participating in training. In the case of Poland, Lithuania and Cyprus respondents mostly indicated three types of difficulties: too high fees for participation in trainings/courses $(94 \%$ in Poland, $100 \%$ in Lithuania, $81 \%$ in Cyprus), insufficient help from the government in the form of subsidies for trainings/ courses (74\% in Poland, 96\% in Lithuania, 78\% in Cyprus) and lack of childcare during the courses/training (71\% in Poland, $81 \%$ in Lithuania, $75 \%$ in Cyprus). The situation is slightly different in Spain, where the three main problems were indicated as: too little help from the government in the form of subsidies for training/courses (75\%), not enough offers of interesting training/courses (66\%) and no scholarships paid during the training (64\%). Detailed results are presented in Chart 6.

The above results indicate that the most frequently indicated difficulties in participating in training relate to financial issues related to fees for training, too low subsidies for training costs or lack of training scholarships. On the other hand, most respondents, regardless of their country of origin, considered too long duration of training/training as the least important obstacle among all the mentioned. 


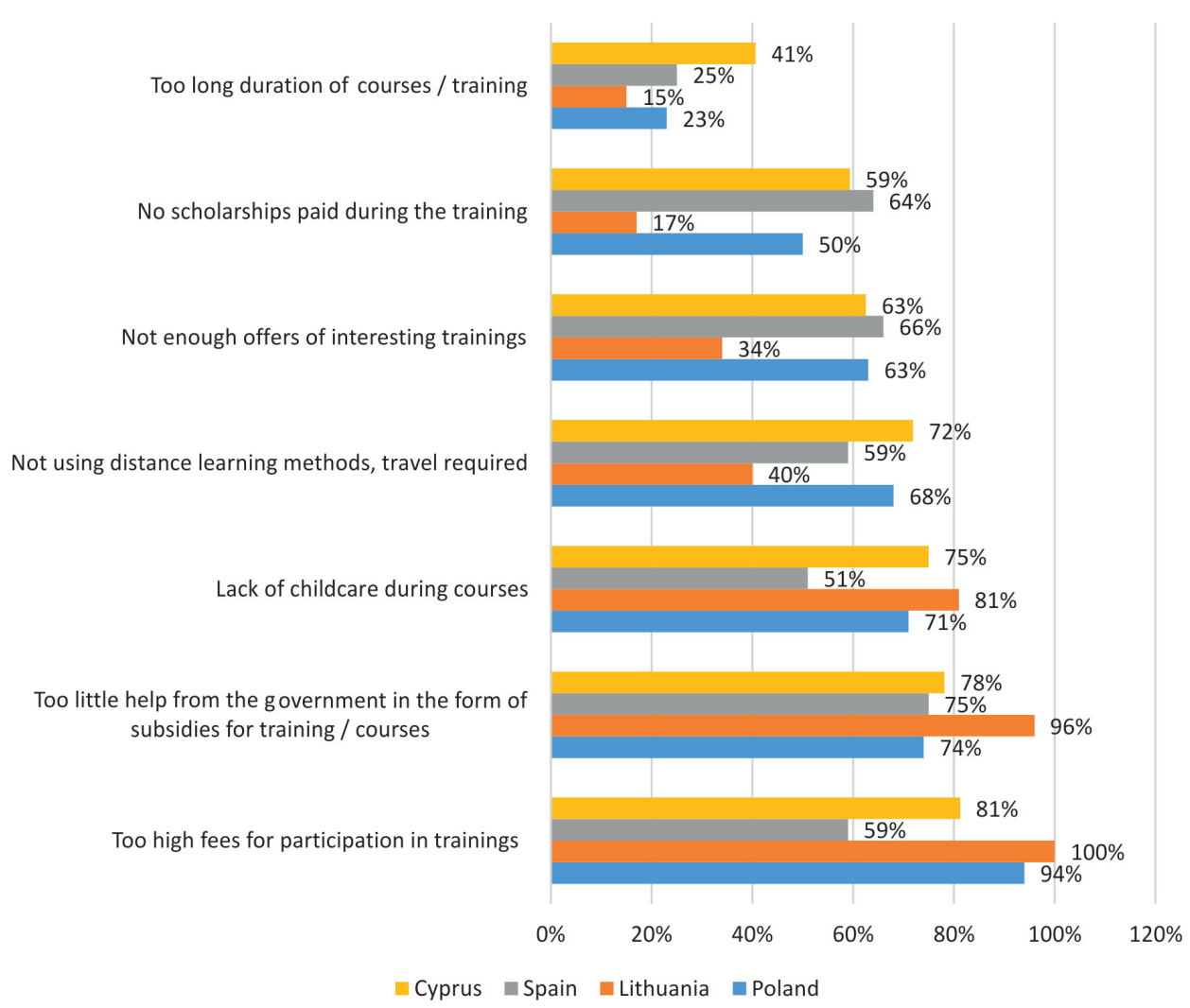

Chart 6. Problems hindering participation in training Source: own study $(\mathrm{N}=217)$.

As far as the difficulties related to the lack of childcare during the courses/ training are concerned, this problem is perceived by about $3 / 4$ of women in Poland, Lithuania and Cyprus, as well as by every second respondent from Spain. In this aspect, the respondents were also asked whether they experienced difficulties in combining participation in training with childcare. More than $2 / 3$ of respondents from Poland, 34\% from Lithuania, less than 20\% from Spain and 47\% from Cyprus answered in the affirmative. Out of this group, the majority of the interviewed women, regardless of their country of origin, managed to overcome these difficulties and to complete the training thanks to the fact that the child was taken care of by the participant's husband/partner or grandmother/grandfather (84\% in Poland, 79\% in Lithuania, 72\% in Spain, 69\% in Cyprus).

It is also worth mentioning the respondents' answers regarding the provision of childcare during the training - respondents were asked if this should be the training organiser's responsibility. Respondents are divided on this issue as 50\% of Polish women, $64 \%$ of Lithuanian women, 53\% of Spanish women and 34\% 
of Cypriot women answered in the affirmative. The majority of respondents in this group believe that such a form of care could be a possibility to place children in a specialised institution cooperating with the organiser free of charge $(52 \%$ of Polish women, $77 \%$ of Lithuanian women, $58 \%$ of Spanish women, $55 \%$ of Cypriot women).

\section{Conclusions}

Answering the research question concerning the participation of women in activities raising the level of competences in the surveyed countries, it should be stated that in each country the majority of surveyed women participated in activities raising the level of competences; the highest percentage in Cyprus ( $72 \%)$, the lowest in Poland (56\%). The differences between the surveyed countries concern the popularity of particular forms of such activities. These results are worth comparing with the results of the Polish study Bilans Kapitatu Ludzkiego 2019 (Balance of Human Capital), where it was shown that $81 \%$ of women aged 18 to 64 have pursued learning in any form in the last 12 months (Górniak et al. 2020: 28).

Answering the research question on the evaluation of the effectiveness of actions raising competences in the professional area in the surveyed countries, it should be noted that approximately every second respondent in Poland, Spain and Cyprus took actions raising competences, which helped to find a job, change to a better job or get a promotion at work. Differences in this respect can be observed in the case of Lithuania, where only one in four respondents agreed with this statement.

The answer to the research question concerning the factors influencing the respondents' decisions to participate in the chosen form of training in the researched countries is slightly more varied. Respondents' answers regardless of country are consistent on the key criteria influencing the decision to participate in training. These include: attractive training topics, free of charge and attractive and easily accessible training location. However, already in the case of the factors "training is (co-) organised by an entity that is an employer and provides employment opportunities" and "training organised by the government or a public institution", it was noted that these factors turned out to be significantly less important for Lithuanian respondents, compared to the other countries surveyed. Differentiation of needs of respondents was also noticed in the issue of preferred time and form of training delivery. These results may indicate that the needs in terms of preferred time of training are differentiated in relation to individual expectations of participants and depend on other factors, including, among others, personal and professional situation. When interpreting the above research results, it should be taken into account that the research was carried out partly during the Covid-19 pandemic, which to a large extent made it impossible to participate in stationary training and resulted in an increase in the importance of 
online forms of education. In addition, when exploring the reasons for preferences towards particular forms of training, it should also be taken into account that these may reflect respondents' previous experiences of onsite and online education, as well as their level of digital competence required to participate effectively in online training.

The answer to the research question regarding the attitudes of the respondents' external environment towards their participation in training courses did not indicate any clear cross-cultural differences in this regard. The vast majority of female respondents from all surveyed countries participating in training feel supported by both family members and friends and acquaintances.

When answering the last research question concerning perceived problems which make it difficult for respondents to participate in trainings, it should be indicated that in case of Poland, Lithuania and Cyprus respondents mostly indicated three types of difficulties: too high charges for participation in trainings/courses, too little help from the government in the form of subsidies for trainings/courses and lack of childcare during the courses/training. Slightly different difficulties were highlighted by Spanish respondents: too little government support in the form of subsidies for training/courses, too few interesting training/courses on offer, and no scholarships paid during the training. In addition to the indicated difficulties related to the financial aspect of participation in training, a significant problem for some of the surveyed women was the lack of childcare during the training. Difficulties in combining participation in training with childcare were experienced by more than $2 / 3$ of respondents from Poland, 34\% from Lithuania, less than $20 \%$ from Spain and $47 \%$ from Cyprus, which indicates clear cross-cultural differences in this respect between the countries under study.

The presented results of the research can be the basis for creating practical implications for entities and institutions implementing training addressed to the researched group of women. As it results from the research results, a key criterion influencing the decision on participation in training is an attractive topic, adjusted to the needs of the target group. Therefore, it is recommended to conduct a thorough research of training needs before starting further activities, inter alia, in terms of interest of potential participants in the given topic of the training and usefulness of the competences acquired during the training in the professional area.

Undoubtedly, financial aspects connected with participation in activities improving competences turned out to be important for the women surveyed. Respondents paid attention to fees for training and the possibility of obtaining co-financing for this purpose. Another important area for some of the interviewed women is child care during the training. Therefore, it is suggested that institutions undertaking training activities aimed at women who are mothers should consider supporting participants in this area, for example, through the possibility of entrusting children free of charge to a specialised institution cooperating with the organiser. 
As can be seen from the presented results, women's expectations in relation to the time and form of training are very diverse, also among respondents coming from the same country. At the same time, for most of the surveyed women an attractive and easily accessible location of training is an important factor influencing participation in training. Therefore, it is recommended that the offered activities improving competences are, as far as possible, implemented on different days and hours (e.g. morning and evening groups) and in different forms, both stationary and remote, which will undoubtedly affect the attendance and higher probability of completing the training by young women/mothers. Diversification of the training offer and taking into account the specific situation of young women, especially mothers, their specific family situation, may contribute to better responding to the needs of women in terms of participation in activities raising the level of competences.

\section{Bibliography}

Dobroszek K. (2021), Fatalna sytuacja matek na rynku pracy. „Zarabiaja nawet o 20 proc. mniej od wspótpracowników", https://mycompanypolska.pl/artykul/fatalna-sytuacja-matekna-rynku-pracy-\%22zarabiaja-nawet-o-20-proc-mniej-od-wspolpracownikow\%22/6894 (accessed: 30.05.2021).

Dolan P., Peasgood T., White M. (2008), Do We Really Know What Makes Us Happy? A Review of the Economic Literature on the Factors Associated With Subjective Well-Being, "Journal of Economic Psychology", vol. 29(1), https://doi.org/10.1016/j.joep.2007.09.001

Domański S.R. (1993), Kapitał ludzki i wzrost gospodarczy, PWN, Warszawa.

Dzwonkowska-Godula K., Garncarek E. (2013), Family and work, family or work - the dilemmas of young educated Poles, "Acta Universitatis Lodziensis. Folia Sociologica", vol. 43.

Eurostat (2020), Being young in Europe today - labour market - access and participation, https:// ec.europa.eu/eurostat/statistics-explained/index.php/Being_young_in_Europe_today_labour_market_-_access_and_participation (accessed: 1.03.2021).

Garncarek E. (2013), Gender and Education in Poland, [in:] C. Quaiser-Poh1, V. Ruthsatz, M. Endepohls-Ulpe (eds.), Diversity and Diversity Management in Education, Waxmann, Münster.

Główny Urząd Statystyczny (GUS) (2019), Praca a obowiazki rodzinne w 2018 r. [Reconciliation between work and family life in 2018], Departament Rynku Pracy [Statistics Poland, Labour Market Department], https://stat.gov.pl/obszary-tematyczne/rynek-pracy/ pracujacy-bezrobotni-bierni-zawodowo-wg-bael/praca-a-obowiazki-rodzinne-w-2018roku,25,3.html\# (accessed: 20.12.2020).

Główny Urząd Statystyczny (GUS) (2020), Informacje sygnalne. Informacja o rynku pracy w pierwszym kwartale 2020 roku (dane wstepne), Substantive study: Labor Market Department, https://stat.gov.pl/obszary-tematyczne/rynek-pracy/ (accessed: 6.06.2021).

Górniak J., Strzebońska A., Worek B. (2020), Rozwój kompetencji. Uczenie się dorostych i sektor rozwojowy. Bilans Kapitału Ludzkiego 2019, Polska Agencja Rozwoju Przedsiębiorczości, Warszawa. 
Loi D., Patrizio M., Samek M. (2017), Young Women's unemployment in EU, https://www.youthimpact.eu/2020/05/22/young-womens-unemployment-in-eu/ (accessed: 1.03.2021).

Luka płacowa między kobietami a mężczyznami: definicja i przyczyny (2020), News of the European Parliament, https://www.europarl.europa.eu/news/pl/headlines/society/20200109STO69925/ luka-placowa-miedzy-kobietami-a-mezczyznami-definicja-i-przyczyny (accessed: 27.07.2021).

Macierzyństwo a aktywność zawodowa (2021), report of "Rodzic w mieście/Parent in town" Foundation, https://rodzicwmiescie.pl/aktywnosc-zawodowa-a-macierzynstwo/ (accessed: 30.06.2021).

Mikołajczyk M., Stankowska M. (2021), Aktywność zawodowa a macierzyństwo. Perspektywa matek małych dzieci, Wydawnictwo Akademii Pedagogiki Specjalnej im. Marii Grzegorzewskiej, Warszawa.

Pregnancy and Maternity (2018a), Pregnancy and Maternity - Related Discrimination and Disadvantage: Experiences of Mothers, https://www.equalityhumanrights.com/en/managingpregnancy-and-maternity-workplace/pregnancy-and-maternity-discrimination-researchfindings (accessed: 20.12.2020).

Pregnancy and Maternity (2018b), Pregnancy and Maternity - Related Discrimination and Disadvantage: Summary of key findings, https://www.equalityhumanrights.com/en/managingpregnancy-and-maternity-workplace/pregnancy-and-maternity-discrimination-researchfindings (accessed: 20.12.2020).

Rękas M. (2013), Kobiety-matki i ich powrót na rynek pracy po urodzeniu dziecka w wynikach badań, "Studia Ekonomiczne", vol. 161/13 - "Społeczno-ekonomiczne problemy rynku pracy", ed. D. Kotlorz, Uniwersytet Ekonomiczny w Katowicach, https://www.ue.katowice.pl/ jednostki/wydawnictwo/czasopisma-naukowe/studies-in-risk-and-sustainable-developmentryzyko-i-zrownowazony-rozwoj/wydania-w-latach-2013-2020/2013/2013/se-16113-spolecznoekonomiczne-problemy-rynku-pracy-red-dorota-kotlorz.html (accessed: 30.06.2021).

Rokicka E., Przybylski B. (2012), Wyksztatcenie i dodatkowe umiejętności jako komponenty kapitału ludzkiego, [in:] P. Starosta (ed.), Zróżnicowanie zasobów kapitału ludzkiego i spotecznego w regionie łódzkim, Wydawnictwo Uniwersytetu Łódzkiego, Łódź.

Ross C.E., Van Willigen M. (1997), Education and the Subjective Quality of Life, "Journal of Health and Social Behavior", vol. 38(3), pp. 275-297, https://doi.org/10.2307/2955371

Słowik M. (2020), "Pracuj sobie, ale ogarnij też dom”. Zamknięcie uświadomi nam ogrom prac domowych i nierówności zwiazane z ich podziałem?, https://www.wysokieobcasy.pl/ wysokie-obcasy/7,158669,25867481,kobiety-podczas-epidemii-przejmuja-wykonywanieobowiazkow-ktore.html (accessed: 7.06.2021).

Socha M., Sztanderska U. (2002), Strukturalne podstawy bezrobocia w Polsce, Wydawnictwo Naukowe PWN, Warszawa.

Szlendak T. (2010), Socjologia rodziny. Ewolucja, historia, zróżnicowanie, Wydawnictwo Naukowe PWN, Warszawa.

Szyszka M. (2016), Aktywność zawodowa w opinii pracujących kobiet, "Annales Universitatis Mariae Curie-Skłodowska”, vol. XLI(2), sectio I, https://doi.org/10.17951/i.2016.41.2.103

Titkow A., Duch-Krzystoszek D., Budrowska B. (2004), Nieodpłatna praca kobiet. Mity, realia, perspektywy, Wydawnictwo Instytutu Filozofii i Socjologii PAN, Warszawa. 


\title{
POTRZEBY I OCZEKIWANIA MLODYCH KOBIET (MATEK) W ZAKRESIE ROZWOJU KOMPETENCJI ZAWODOWYCH - ANALIZA PORÓWNAWCZA WYNIKÓW BADAŃ Z POLSKI, LITWY, HISZPANII I CYPRU
}

\begin{abstract}
Abstrakt. W ciągu ostatnich dwóch dekad w Unii Europejskiej nastąpiła znacząca poprawa w zakresie udziału kobiet w edukacji i na rynku pracy. Niemniej jednak nadal istnieje wiele wyzwań związanych z poprawą sytuacji tej kategorii społecznej. Nadmierne obciążenie obowiązkami domowymi stanowi główną barierę dla aktywności edukacyjnej i zawodowej kobiet, zwłaszcza młodych matek. Do czynników ograniczających aktywność zawodową kobiet, oprócz niemożności pogodzenia życia zawodowego i osobistego, należy niedopasowanie wykształcenia do wyzwań współczesnego rynku pracy. Mimo że większość osób z wyższym wykształceniem stanowią kobiety, planując swoją karierę zawodową, wybierają one zwykle mniej atrakcyjne kierunki studiów, które nie są związane z zawodami przyszłości. W tekście przedstawiono wyniki analizy badań dotyczących potrzeb i oczekiwań młodych kobiet (głównie matek) w zakresie rozwoju kompetencji zawodowych. Wyniki pokazują, w jakich rodzajach zajęć podnoszących kompetencje uczestniczą badane kobiety; jak oceniają skuteczność zajęć podnoszących ich kompetencje w obszarze zawodowym; jakie czynniki wpływają na decyzję kobiet o udziale w wybranej formie szkolenia; jakie są postawy otoczenia zewnętrznego badanych kobiet wobec ich udziału w szkoleniach; jakie problemy napotykają badane kobiety w związku z udziałem w szkoleniach podnoszących ich kompetencje zawodowe. Skupiono się na podobieństwach i różnicach w wypowiedziach młodych kobiet/matek z Polski, Litwy, Hiszpanii i Cypru, które uczestniczyły w międzynarodowym projekcie „Mommypreneurs”.
\end{abstract}

Słowa kluczowe: młode kobiety, matki, szkolenia, kompetencje, rynek pracy, UE, projekt Mommypreneurs.

Scientific work published within the framework of an international project co-financed by the programme of the Ministry of Science and Higher Education entitled "PMW" in the years 2018-2020; contract no. 5110/EEA NG/2020/0 for the execution of the international project entitled: "Mommypreneurs" (acronym: Mommypreneurs). 